\section{Emission Characteristics and Cancer Risks of Polycyclic Aromatic Hydrocarbon Emissions from Diesel-fueled Vehicles Complying with Recent Regulations}

\author{
Kiriko Kashiwakura*, $a, b$ \\ and Kazuhiko Sakamoto ${ }^{b, c}$
}

${ }^{a}$ Energy and Environmental Research Division, Japan Automobile Research Institute, 2530 Karima, Tsukuba, Ibaraki 305-0822, Japan, ${ }^{b}$ Department of Environmental Science and Technology, Graduate School of Science and Engineering and ${ }^{c}$ Institute for Environmental Science and Technology, Saitama University, 255 Shimo-Okubo, Sakura-ku, Saitama, Saitama 338-8570, Japan

(Received September 11, 2009; Accepted January 21, 2010; Published online January 27, 2010)

Polycyclic aromatic hydrocarbon (PAH) emissions from diesel vehicles have been reduced by recent regulations further dropping the permissible levels of regulated substances. We analyzed emissions of 13 PAHs from cold- or hot-start test cycles in three diesel vehicles complying with these stringent regulations, and we estimated cancer risk in terms of toxic equivalency factors (TEFs). Two vehicles were equipped with oxidation catalysts and one with a urea-selective catalytic reduction (SCR) system. Most PAH emissions were lower from the compliant vehicles than from other diesel vehicles with no aftertreatment devices. For the three vehicles, naphthalene (Naph) was emitted at the highest rate (2.92$376 \mu \mathrm{g} / \mathrm{km}$ ); by mass it constituted 51.1-84.8\% (mean 73.0\%, S.D. $\pm 12.2 \%$ ) of all PAH emissions. However, in the SCR system, Naph emissions probably decomposed during collection, because the percentage recoveries of surrogate were low, suggesting the presence of specific reactive substances in the SCR system exhaust. The cancer risk of PAH emissions was reduced by application of the emission-control devices. Most benzo $[a]$ pyrene-equivalent $\left(B[a] P_{\text {eq }}\right)$

\footnotetext{
*To whom correspondence should be addressed: Energy and Environmental Research Division, Japan Automobile Research Institute, 2530 Karima, Tsukuba, Ibaraki 305-0822, Japan. Tel.: +81-29-856-0872; Fax: +81-29-856-1134; E-mail: kkiriko@jari.or.jp
}

— Researth Letter -

emissions of two-ring PAHs (Naph) or total emissions of five-ring PAHs like benzo $[a]$ pyrene were greater than those of other-ring PAHs. Although Naph has a low TEF (0.001), it constituted a high proportion of the total $B[a] P_{e q}(26-74 \%$; mean $54 \%$, S.D. \pm $15 \%)$. The contents of particulate five-ring PAHs, which pose high cancer risks, are decreasing because of improvements in emissions-reduction technology. Hence, the relative contribution of Naph as a gaseous PAH to the TEF-determined risk of carcinogenesis is increasing.

Key words — polycyclic aromatic hydrocarbon, diesel emission, cancer risk, toxic equivalency factor

\section{INTRODUCTION}

The mechanism of carcinogenesis of polycyclic aromatic hydrocarbons (PAHs) is similar to that of dioxins. The aryl hydrocarbon receptor (AhR) is a well established receptor for PAHs and dioxins. PAHs induce tumors in part by activating the AhR/transcription factor. ${ }^{1-3)}$ Toxic equivalency factors (TEFs) are tools for health-risk assessment of PAHs. Risk assessments of PAHs and attempts to derive TEFs as indicators of the relative potency of individual PAHs have been performed in several studies for the purpose of summarizing the cancer risk contributions of total benzo $[a]$ pyreneequivalent $\left(\mathrm{B}[\mathrm{a}] \mathrm{P}_{\mathrm{eq}}\right)$ doses. $^{4-7)}$

Diesel exhaust is an important source of PAHs in ambient air. Particulate PAHs such as B[a]P in diesel exhaust have been a focus of attention because of their carcinogenicity or mutagenicity. ${ }^{8)}$ However, particulate PAH emissions have tended to decrease as a result of advances in combustion control system design, the fitting of emission after-treatment devices, and the reduction of sulfur levels in fuel. ${ }^{9}{ }^{10)}$ However, data on the emission of volatile and semivolatile PAHs from recentmodel diesel vehicles incorporating these advances are few.

The purpose of this investigation was to clarify the characteristics of PAH emissions from vehicles complying with the recent, stringent emissions regulations. Three heavy-duty diesel vehicles were driven on cold- and/or hot-start test cycles. We measured the emissions of 13 PAHs, including volatile and semivolatile PAHs, to evaluate the cancer risks 
posed by PAHs in diesel exhaust. Cancer risk was calculated by using $\mathrm{TEFs}^{5)}$ in accordance with the number of aromatic rings.

\section{MATERIALS AND METHODS}

Vehicles and Fuels — The specifications of the heavy-duty diesel vehicles and fuels tested are shown in Table 1. HD-1 and HD-2 complied with the new (2003) short-term Japanese emission regulation. HD-3 complied with the new (2005) longterm Japanese emission regulation. These two regulations differ in terms of regulation values. Particularly nitrogen oxide $\left(\mathrm{NO}_{x}\right)$ and particulate matter regulation values of the new long-term are more severe than the new short-term ones. Every test vehicle had exhaust gas recirculation (EGR) for $\mathrm{NO}_{x}$ emission-reduction. HD-1 and HD-2 had an oxidation catalyst as a hydrocarbon emission-reduction device. HD-3 had a urea-selective catalytic reduction (SCR) system that consisted of one de- $\mathrm{NO}_{x}$ catalyst and two oxidation catalysts. The fuels used for the testing differed in sulfur density. Fuel containing $30 \mathrm{ppm}(\mathrm{w} / \mathrm{w})$ sulfur was used in HD-1. Fuel containing $4.0 \mathrm{ppm}(\mathrm{w} / \mathrm{w})$ sulfur was used in HD-2 and HD-3.

Diluted Exhaust-Collection Method — Empore extraction disk (EPD) filters containing XAD-2 resin (SDB-XC 90-mm diameter; $3 \mathrm{M}$ Corporation, St. Paul, MN, U.S.A.) were used for PAHs correction.

To prepare the filters, they were first washed with dichloromethane [pesticide residue analysis and polychlorinated biphenyl (PCB) analytical grade; Wako Pure Chemical Industries Inc., Osaka, Japan] in a Soxhlet apparatus (Shibata Glass Factory, Tokyo, Japan). The filters were then dried in a draft at room temperature and cut to a diameter of $70 \mathrm{~mm}$ with a stainless-steel punch.

For quantification of artificial effects during PAHs collection, the cut filters were spiked with three deuterium-labeled PAHs (PAHs-d; Daiichi Pure Chemicals Co., Tokyo, Japan) in acetonitrile solution: naphthalene- $d_{8}$ (Naph-d) at $400 \mathrm{ng} /$ filter; pyrene- $d_{10}\left(\right.$ Pyre-d) at $100 \mathrm{ng} /$ filter; and B[a]P- $d_{12}$ (B[a]P-d) at $200 \mathrm{ng} /$ filter. They were then dried again in a draft and placed in plastic petri dishes. The percent recoveries of these PAHs-d were determined. After pretreatment as described above, the filters in petri dishes were stored in aluminum bags together with charcoal cloth until PAHs collection.

The PAHs collection detail is shown in Fig. 1. The vehicles were operated on a chassis dynamometer at half payload. The exhausts of HD-1 were introduced into a full-flow dilution tunnel and were diluted by means of a constant-volume sampler (CVS; CVS 9400T, Horiba, Kyoto, Japan). The exhausts of HD-2 and HD-3 were diluted by means of a CVS (DLT-1890 W, Horiba) with a dilution air refiner.

For PAHs collection, a pretreated EPD filter was placed in the stainless-steel filter holder. The diluted exhausts were collected at an isokinetic collecting flow rate of $20 \mathrm{l} / \mathrm{min}(9.3 \mathrm{~cm} / \mathrm{s})$ at the end of the dilution tunnel, in the tunnel's cross-sectional center. At the collection flow rate, we tested breakthrough of PAHs measured preliminarily. Diluted exhaust of a heavy-duty diesel vehicle with no emissioncontrol devices and driven at a steady state of speed of $80 \mathrm{~km} / \mathrm{h}(\mathrm{S} . \mathrm{S} .80 \mathrm{~km} / \mathrm{h})$ was collected by two EPD

Table 1. Specification of Test Heavy-duty Diesel Vehicles and Fuels

\begin{tabular}{|c|c|c|c|}
\hline Vehicle number & HD-1 & HD-2 & HD-3 \\
\hline Regulation year for Japan & 2003 & 2003 & 2005 \\
\hline Maximum payload & $2000 \mathrm{~kg}$ & $2000 \mathrm{~kg}$ & $16000 \mathrm{~kg}$ \\
\hline Gross vehicle weight & $5100 \mathrm{~kg}$ & $4600 \mathrm{~kg}$ & $25000 \mathrm{~kg}$ \\
\hline Displacement & $4800 \mathrm{ml}$ & $4800 \mathrm{ml}$ & $9200 \mathrm{ml}$ \\
\hline Emission control device & $\begin{array}{l}\text { Common-rail, }{ }^{a)} \text { EGR, }{ }^{b)} \\
\text { Oxidation catalyst }\end{array}$ & $\begin{array}{l}\text { Common-rail, EGR, } \\
\text { Oxidation catalyst }\end{array}$ & $\begin{array}{l}\text { Common-rail, EGR, Oxida- } \\
\text { tion catalyst, Urea SCR }\end{array}$ \\
\hline Fuel type & $\mathrm{JIS} \mathrm{\# 2^{c) }}$ & JIS \#2 & JIS \#2 \\
\hline Sulfur in fuel & $30 \mathrm{ppm}(\mathrm{w} / \mathrm{w})$ & $4.0 \mathrm{ppm}(\mathrm{w} / \mathrm{w})$ & $4.0 \mathrm{ppm}(\mathrm{w} / \mathrm{w})$ \\
\hline Total aromatics in fuel & $20.9 \%(\mathrm{w} / \mathrm{w})$ & $16.5 \%(\mathrm{w} / \mathrm{w})$ & $16.5 \%(\mathrm{w} / \mathrm{w})$ \\
\hline Test cycle (start-up & S.S. $80 \mathrm{~km} / \mathrm{h}^{d)}(\mathrm{hot}, n=2)$ & & S.S. $80 \mathrm{~km} / \mathrm{h}(\mathrm{hot}, n=2)$ \\
\hline conditions, number & & JE05 (hot, $n=1$ ) & JE05 (hot, $n=2)$ \\
\hline of tests) & & JE05 (cold, $n=2$ ) & JE05 (cold, $n=2)$ \\
\hline
\end{tabular}

a) Common-rail fuel injection. $b$ ) Exhaust gas recirculation. $c$ ) Japanese industrial standards \#2 diesel fuel. $d$ ) Steady state of speed $80 \mathrm{~km} / \mathrm{h}$. 


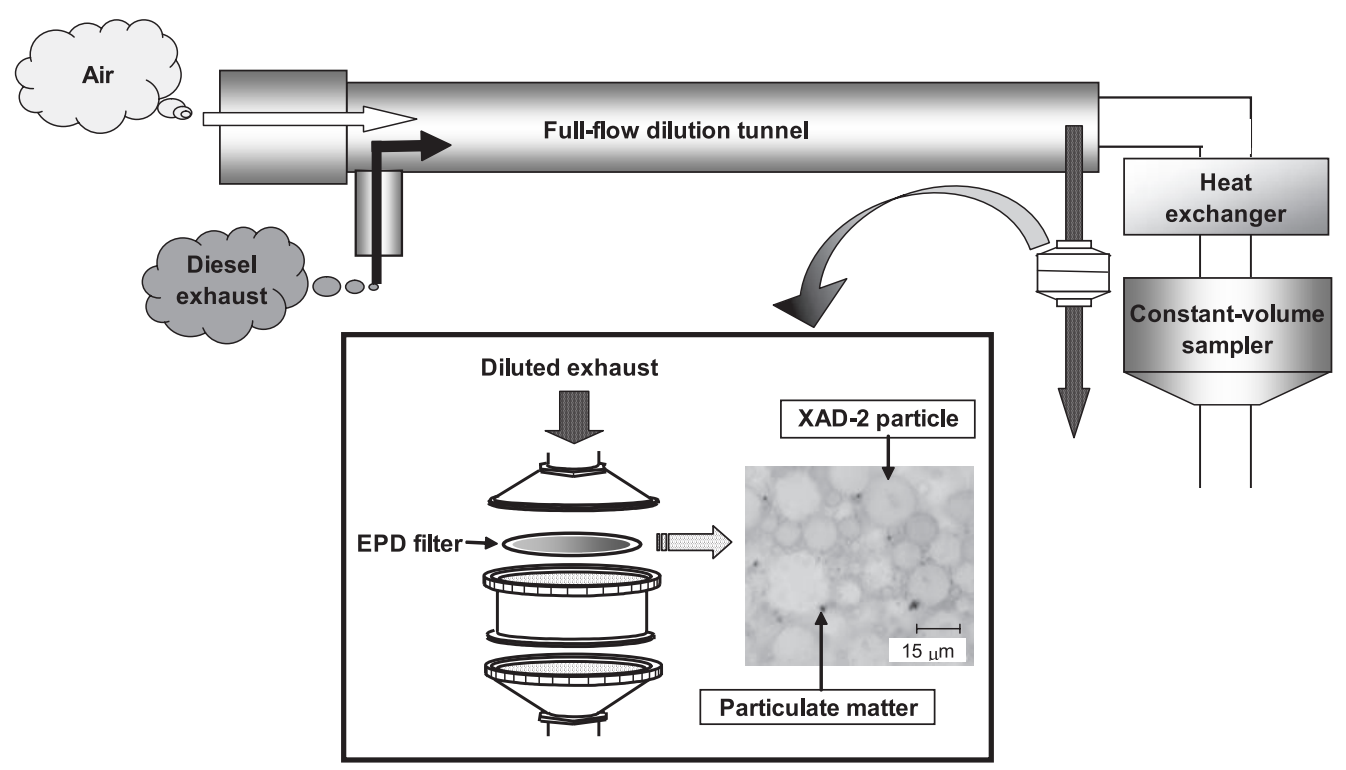

Fig. 1. Apparatus for Sampling PAHs from Diluted Diesel Exhaust CVS, constant-volume sampler.

filters over a period of $3600 \mathrm{~s}$. We confirmed no breakthrough of measured PAHs onto the second EPD filter, which was placed downstream of the first EPD filter for PAH collection.

The diluted exhaust of HD-1, driven at an S.S. $80 \mathrm{~km} / \mathrm{h}$, was collected with an EPD filter over a period of $1200 \mathrm{~s}$. The diluted exhausts of HD-2 and HD-3 driven at JE05 cold- and hot-start test cycles (cycle duration: $1829 \mathrm{~s}$ ) ${ }^{11)}$ were collected with an EPD filter. The JE05 transient cycle simulates real driving conditions. Furthermore, the exhaust of HD-3 driven at an S.S. $80 \mathrm{~km} / \mathrm{h}$ was collected with an EPD filter over a period of $1800 \mathrm{~s}$. The collection time for HD-3 was longer than that for HD-1 because the lower emission rates of the former by two oxidation catalysts of SCR system were estimated. After collection of the diluted exhaust, the EPD filter was packed in the aluminum bag and then stored in a refrigerator at lower temperature than $-20^{\circ} \mathrm{C}$ until the PAHs were extracted.

PAH Analysis — The PAHs analyzed were Naph, fluorene (Flre), phenanthrene (Phen), fluoranthene (Flra), anthracene (Anth), Pyre, benz $[a]$ anthracene $(\mathrm{B}[\mathrm{a}] \mathrm{A})$, benzo[b]fluoranthene $(\mathrm{B}[\mathrm{b}] \mathrm{F})$, benzo[k]fluoranthene $(\mathrm{B}[\mathrm{k}] \mathrm{F}), \mathrm{B}[\mathrm{a}] \mathrm{P}$, benzo[ghi] perylene $(\mathrm{B}[\mathrm{ghi}] \mathrm{P}), \operatorname{dibenz}[a, h]$ anthracene $(\mathrm{DB}$ [ah]A), and indeno[1,2,3-cd]pyrene (I[cd]P). PAHs were extracted from each EPD filter with $c a .150 \mathrm{ml}$ of dichloromethane for $24 \mathrm{hr}$ in a Soxhlet extractor in a water bath at $60^{\circ} \mathrm{C}$. Dimethyl sulfoxide (HPLC grade, $100 \mu \mathrm{l}$; Dojindokagaku, Kumamoto,
Japan) was added to prevent evaporation to dryness, and the solution was concentrated to $100 \mu \mathrm{l}$ with a Kuderna-Danish concentrator. After concentration, the residue was diluted with $1 \mathrm{ml}$ of methanol (HPLC analytical grade; Wako Pure Chemical Industries Inc.), and the resulting solution was filtered through membrane filters (Ekicrodisc 3CR; Gelman Sciences Inc., Ann Arbor, MI, U.S.A.). The analysis was performed by reverse-phase HPLC with two fluorescence detectors (RF-10A XL; Shimadzu, Kyoto, Japan) connected in series, because number of PAHs to analyse PAHs were many. The detection wavelengths were changed based on corresponding PAHs. Excitation and emission wavelengths for the 13 PAHs are shown in Table 2, with the limits of detection (LODs), together with the TEFs proposed by Nisbet and Lagoy. ${ }^{5)}$ PAHs were separated on a guard column (Cartridge guard column E, $10 \mathrm{~mm} \times 3.0 \mathrm{~mm}$ Inside diameter (ID); GL Science, Tokyo, Japan) and two main columns (Inertsil ODS$\mathrm{P}, 100 \mathrm{~mm} \times 4.6 \mathrm{~mm} \mathrm{ID}+250 \mathrm{~mm} \times 4.6 \mathrm{~mm} \mathrm{ID}$; GL Science). The column temperature was set at $40^{\circ} \mathrm{C}$. A mobile-phase solvent gradient of acetonitrile (aldehyde analytical grade; Wako Pure Chemical Industries Inc.) and deionized distilled water (50:50) was held isocratically for $10 \mathrm{~min}$, changed linearly to $95 \%$ acetonitrile over $40 \mathrm{~min}$, and then held at $95 \%$ acetonitrile for $10 \mathrm{~min}$. The flow rate of the mobile phase was $1 \mathrm{ml} / \mathrm{min}$. Standard Reference Material 1647d (SRM 1647d; National Institute of Standards and Technology, Gaithersburg, 
MD, U.S.A.) which contained all 13 PAHs was used as a calibration standard. The validity of the method from extraction to analysis was confirmed by the percentage recoveries of the 13 PAHs, as follows $(n=4)$. SRM $1647 \mathrm{~d}$ was diluted 10 times with acetonitrile and a $100-\mu l$ aliquot was added to each EPD filter. The percentage recovery of Naph was only slightly lower (78-97\%) than the recovery of the other PAHs (90-110\%). Therefore, $\mathrm{PAH}$ losses in the period from extraction to analysis were low. In addition, we confirmed the percentage recoveries of PAHs-d in HD-3 experiment. Two

Table 2. Fluorescence Detection Wavelengths, LODs, and TEFs of Analyzed PAHs

\begin{tabular}{lccll}
\hline \hline PAH & $\begin{array}{c}\text { Fluorescence detection } \\
\text { wavelength }\end{array}$ & $\begin{array}{c}\text { LOD } \\
\text { (ng/filter })\end{array}$ & TEF \\
\cline { 2 - 3 } & $\begin{array}{c}\text { Excitation } \\
(\mathrm{nm})\end{array}$ & $\begin{array}{c}\text { Emission } \\
(\mathrm{nm})\end{array}$ & & \\
\hline Naph & 283 & 330 & 3.6 & 0.001 \\
Flre & 268 & 304 & 0.90 & 0.001 \\
Phen & 296 & 367 & 1.2 & 0.001 \\
Anth & 375 & 403 & 0.62 & 0.01 \\
Flra & 352 & 452 & 1.3 & 0.001 \\
Pyre & 340 & 393 & 1.6 & 0.001 \\
B[a]A & 293 & 415 & 0.61 & 0.1 \\
B[b]F & 306 & 455 & 0.41 & 0.1 \\
B[k]F & 382 & 407 & 0.10 & 0.1 \\
B[a]P & 382 & 407 & 0.13 & 1 \\
DB[ah]A & 302 & 400 & 0.29 & 5 \\
B[ghi]P & 382 & 407 & 0.34 & 0.01 \\
I[cd]P & 388 & 508 & 0.30 & 0.1 \\
\hline
\end{tabular}

spiked filters were used for collection of dilution air. After 30 min collection, the percentage recoveries of Naph-d were $72.6 \%$ and $71.6 \%$; of Pyre$\mathrm{d}$ were $103 \%$ and $99.5 \%$; of B[a]P-d were $99.2 \%$ and $100 \%$. Since the percentage recoveries were same levels as described percentage recoveries of 13 PAHs, drying after PAHs-d spiking and dilution air had no effect on PAHs-d loss.

\section{RESULTS AND DISCUSSION}

\section{Emission Characteristics of PAHs}

The PAH emissions from each test vehicle and the percentage recoveries of PAHs-d are shown in Table 3. Naph and Phen were present in all tests performed. Naph had the highest emission rate of $2.92-376 \mu \mathrm{g} / \mathrm{km}$; it constituted $51.1-84.8 \%$ (mean $73.0 \%$, S.D. $\pm 12.2 \%$ ) of the total PAH emission. In contrast, DB[ah]A and I[cd]P were not detected or were below the LOD in all tests.

The start condition of test cycle influences emission significantly. Under the cold-start condition, the vehicle emissions tend to be higher than under hot-start condition ${ }^{12)}$ because of low temperature of a catalyst. For HD-2, the total PAH emissions under cold-start conditions were 1.3 and 1.4 times those under hot-start conditions. For HD-3, the total PAH emissions under cold-start conditions were same level of those under hot-start conditions; this result reflected the low percentage recoveries of Naph-d under cold-start conditions. The percentage

Table 3. Emissions of Individual PAHs $(\mu \mathrm{g} / \mathrm{km})$ from the Test Vehicles

\begin{tabular}{|c|c|c|c|c|c|c|c|c|c|c|c|}
\hline \multirow[t]{3}{*}{ PAHs } & \multirow{2}{*}{\multicolumn{2}{|c|}{$\begin{array}{c}\text { HD-1 } \\
\text { S.S. } 80 \mathrm{~km} / \mathrm{h}(n=2)\end{array}$}} & \multicolumn{3}{|c|}{ HD-2 } & \multicolumn{6}{|c|}{ HD-3 } \\
\hline & & & \multicolumn{2}{|c|}{ JE05 cold $(n=2)$} & \multirow{2}{*}{$\begin{array}{l}\text { JE05 hot } \\
(n=1)\end{array}$} & \multicolumn{2}{|c|}{ JE05 cold $(n=2)$} & \multicolumn{2}{|c|}{ JE05 hot $(n=2)$} & \multicolumn{2}{|c|}{ S.S. $80 \mathrm{~km} / \mathrm{h}(n=2)$} \\
\hline & 1 st test & 2nd test & 1st test & 2nd test & & 1st test & 2nd test & 1st test & 2nd test & 1st test & 2nd test \\
\hline Naph & 197 & 254 & 376 & 343 & 233 & 3.91 & 3.18 & 6.36 & 4.07 & 5.06 & 2.92 \\
\hline Flre & 5.75 & 8.12 & 12.9 & 11.7 & 9.09 & N.D. & N.D. & N.D. & N.D. & N.D. & N.D. \\
\hline Phen & 30.4 & 33.5 & 49.2 & 49.3 & 59.0 & 1.96 & 1.56 & 1.56 & 1.65 & 1.29 & 0.994 \\
\hline Anth & 0.374 & 0.667 & 1.60 & 1.74 & 2.08 & $<$ LOD & $<$ LOD & $<$ LOD & $<$ LOD & N.D. & N.D. \\
\hline Flra & 1.89 & 2.04 & 3.02 & 2.95 & 4.01 & 0.607 & 0.524 & $<$ LOD & $<$ LOD & $<$ LOD & $<\mathrm{LOD}$ \\
\hline Pyre & 1.18 & 1.21 & 2.45 & 2.31 & 2.80 & 1.01 & 0.952 & 0.661 & 0.636 & 0.275 & $<\mathrm{LOD}$ \\
\hline $\mathrm{B}[\mathrm{a}] \mathrm{A}$ & N.D. & N.D. & 0.252 & 0.291 & 0.199 & N.D. & N.D. & N.D. & N.D. & N.D. & N.D. \\
\hline $\mathrm{B}[\mathrm{b}] \mathrm{F}$ & 0.074 & 0.077 & $<$ LOD & $<$ LOD & $<$ LOD & $<$ LOD & $<$ LOD & $<$ LOD & N.D. & $<$ LOD & N.D. \\
\hline $\mathrm{B}[\mathrm{k}] \mathrm{F}$ & 0.010 & 0.013 & $<$ LOD & $<$ LOD & $<$ LOD & N.D. & N.D. & N.D. & N.D. & N.D. & N.D. \\
\hline $\mathrm{B}[\mathrm{a}] \mathrm{P}$ & 0.043 & 0.074 & 0.136 & 0.136 & 0.124 & $<$ LOD & $<$ LOD & $<$ LOD & $<$ LOD & N.D. & $<$ LOD \\
\hline $\mathrm{DB}[\mathrm{ah}] \mathrm{A}$ & N.D. & N.D. & N.D. & N.D. & N.D. & N.D. & N.D. & N.D. & N.D. & N.D. & N.D. \\
\hline $\mathrm{B}$ [ghi]P & N.D. & N.D. & 0.076 & 0.076 & 0.051 & N.D. & N.D. & N.D. & N.D. & N.D. & N.D. \\
\hline $\mathrm{I}[\mathrm{cd}] \mathrm{P}$ & N.D. & N.D. & N.D. & N.D. & N.D. & N.D. & $<$ LOD & N.D. & N.D. & $<$ LOD & $<$ LOD \\
\hline Total PAHs & 237 & 300 & 446 & 412 & 310 & 7.48 & 6.22 & 8.58 & 6.36 & 6.62 & 3.91 \\
\hline \multicolumn{12}{|c|}{ Percent recovery $(\%)$} \\
\hline Naph-d & 71.2 & 93.2 & 99.2 & 107 & 104 & 39.9 & 22.0 & 89.9 & 70.7 & 65.7 & 64.0 \\
\hline Pyre-d & 103 & 97.7 & 99.8 & 93.2 & 103 & 97.5 & 93.8 & 106 & 94.8 & 89.6 & 87.1 \\
\hline $\mathrm{B}[\mathrm{a}] \mathrm{P}-\mathrm{d}$ & 44.4 & 67.6 & 39.1 & 39.0 & 35.4 & 25.1 & 21.8 & 33.7 & 37.9 & 32.2 & 31.5 \\
\hline
\end{tabular}


recoveries of Naph-d under cold-start conditions were lower than under hot-start conditions. After correction of HD-3 Naph values by each percentage recovery, the total PAH emissions under cold-start conditions were from 1.4 to 2.2 times those under hot-start conditions.

$\mathrm{B}[\mathrm{a}] \mathrm{P}$ emissions were detected from HD-1 and HD-2. The B[a]P-d percentage recoveries were low, at $35.4-67.6 \%$ (mean $45.1 \%$, S.D. $\pm 13.0 \%$ ). This indicated that $\mathrm{B}[\mathrm{a}] \mathrm{P}$ emissions from the test vehicles were underestimated. Esteve et al. ${ }^{13)}$ investigated the reaction of $\mathrm{NO}_{2}$ and $\mathrm{OH}$ radicals with PAHs adsorbed on diesel exhaust particles by exposing the particles to gaseous $\mathrm{NO}_{2}$ at $8.0 \times 10^{13}$ molecules $/ \mathrm{cm}^{3}$ (3.2 ppm) in a flow tube; they found that $\mathrm{B}[\mathrm{a}] \mathrm{P}$ was the most reactive $\mathrm{PAH}$, with degradation of $25 \pm 7 \%$ over $1800 \mathrm{~s}$. The other PAHs, such as Phen and B[a]A, had degradation yields of $10 \%$ and $14 \%$, respectively. Oxidation catalysts that are known to increase $\mathrm{NO}_{2}$ emissions ${ }^{14-16)}$ were attached to the test vehicles. Therefore, the low recovery rates of $\mathrm{B}[\mathrm{a}] \mathrm{P}-\mathrm{d}$ observed from HD-1 and HD-2 are likely to have been caused by oxidation by substances in the exhausts, such as $\mathrm{NO}_{2}$, during collection. In the case of HD-3, with its SCR system for hydrocarbon and $\mathrm{NO}_{x}$ reduction, the percent- age recoveries of $\mathrm{B}[\mathrm{a}] \mathrm{P}-\mathrm{d}$ were lower than in HD-1 and -2 (21.8-37.9\%; mean 30.4\%, S.D. $\pm 5.9 \%)$. In addition, the percentage recoveries of Naph-d were low (22.0-89.9\%; mean 58.7\%, S.D. $\pm 24.1 \%)$. Because of the low recovery of Naph-d, the PAH emissions of HD-3 were more underestimated. Therefore, although the SCR system reduces PAH emissions, it is possible that reactive substances that degrade PAHs during collection are present in the exhausts. The reactive substances are unknown, but they are probably substances characteristic of the SCR system, such as isocyanic acid. ${ }^{17-19)}$ Kleemann et al. ${ }^{19)}$ investigated the hydrolysis of isocyanic acid on oxidation catalysts in a plug flow microreactor. The conversions of isocyanic acid were high at the high space velocities and low temperatures. However, the conversion under $190^{\circ} \mathrm{C}$ was $93.7 \%$. Hence, isocyanic acid was slightly remaining and emitted in exhaust of cold-start condition.

Table 4 shows PAH emissions identified by other authors. ${ }^{20-22)}$ Test vehicles with no aftertreatment devices met foreign emissions regulations in the latter half of the $1990 \mathrm{~s}$. Rogge et al. ${ }^{20)}$ used quartz filters to collect PAHs and measured particulate PAHs. Schauer et al. ${ }^{21)}$ and Nelson et al. ${ }^{22)}$ divided PAHs into particle and gas forms and mea-

Table 4. Emissions of Individual PAHs in Various Studies

\begin{tabular}{|c|c|c|c|c|}
\hline \multirow[b]{2}{*}{ Vehicle class } & \multirow{2}{*}{$\begin{array}{c}\text { Rogge } \text { et al. }(1993)^{20)} \\
\text { HD }^{a)} \text { truck }\end{array}$} & \multirow{2}{*}{$\frac{{\text { Schauer } \text { et al. }(1999)^{21)}}_{\mathrm{MD}^{b)} \text { truck }}}{}$} & \multicolumn{2}{|c|}{ Nelson et al. $(2008)^{22)}$} \\
\hline & & & $\mathrm{NA}^{c)}$ & $\mathrm{NC}^{d)}$ \\
\hline $\mathrm{GVM}^{e)}$ & & & $2580 \mathrm{~kg}$ & $16000 \mathrm{~kg}$ \\
\hline Test cycle & Diesel driving cycle $f$ ) & FTP 75 cycle $^{g)}$ (hot start) & CUEDC $^{h)}$ & CUEDC $^{i}$ \\
\hline Sulfur in fuel & & & \multicolumn{2}{|c|}{$39 \mathrm{ppm}(\mathrm{w} / \mathrm{w})$} \\
\hline Total aromatics in fuel & & & \multicolumn{2}{|c|}{$11.6 \%(\mathrm{w} / \mathrm{w})$} \\
\hline \multicolumn{5}{|l|}{ Species $(\mu \mathrm{g} / \mathrm{km})$} \\
\hline Naph & & 617 & 562 & 2720 \\
\hline Flre & & 44.1 & 5.2 & 51.6 \\
\hline Phen & 12.2 & 140.1 & 33 & 110 \\
\hline Anth & 1.6 & 23.4 & 1.5 & 6.3 \\
\hline Flra & 13.0 & 109.6 & 5.6 & 8.1 \\
\hline Pyre & 22.6 & 160.4 & 5.6 & 13.8 \\
\hline $\mathrm{B}[\mathrm{a}] \mathrm{A}$ & 3.6 & 10.74 & 0.6 & 0.6 \\
\hline $\mathrm{B}[\mathrm{b}] \mathrm{F}$ & 2.9 & & 0.6 & 1.6 \\
\hline $\mathrm{B}[\mathrm{k}] \mathrm{F}$ & 2.7 & & 0.6 & 1.6 \\
\hline $\mathrm{B}[\mathrm{a}] \mathrm{P}$ & 1.3 & & 0.6 & 1.6 \\
\hline $\mathrm{DB}[\mathrm{ah}] \mathrm{A}$ & N.D. & & & \\
\hline $\mathrm{B}$ [ghi]P & 1.6 & & 0.6 & 1.3 \\
\hline $\mathrm{I}[\mathrm{cd}] \mathrm{P}$ & N.D. & & 0.3 & \\
\hline Total PAHs & 61.5 & 1105 & 616 & 2920 \\
\hline
\end{tabular}

a) Heavy duty. $b$ ) Medium duty. c) Light commercial < 3.5 t gross vehicle mass (GVM). $d$ ) Rigid truck 12.5 to 25 t GVM. e) Gross vehicle mass. $f$ ) Driving cycle for heavy-duty diesel trucks. $g$ ) Federal Test Procedure 75 emission test cycle of U.S.A. h) Composite Urban Emission Drive Cycle of Australia for NA category vehicles. i) Composite Urban Emission Drive Cycle of Australia for NC category vehicles. 


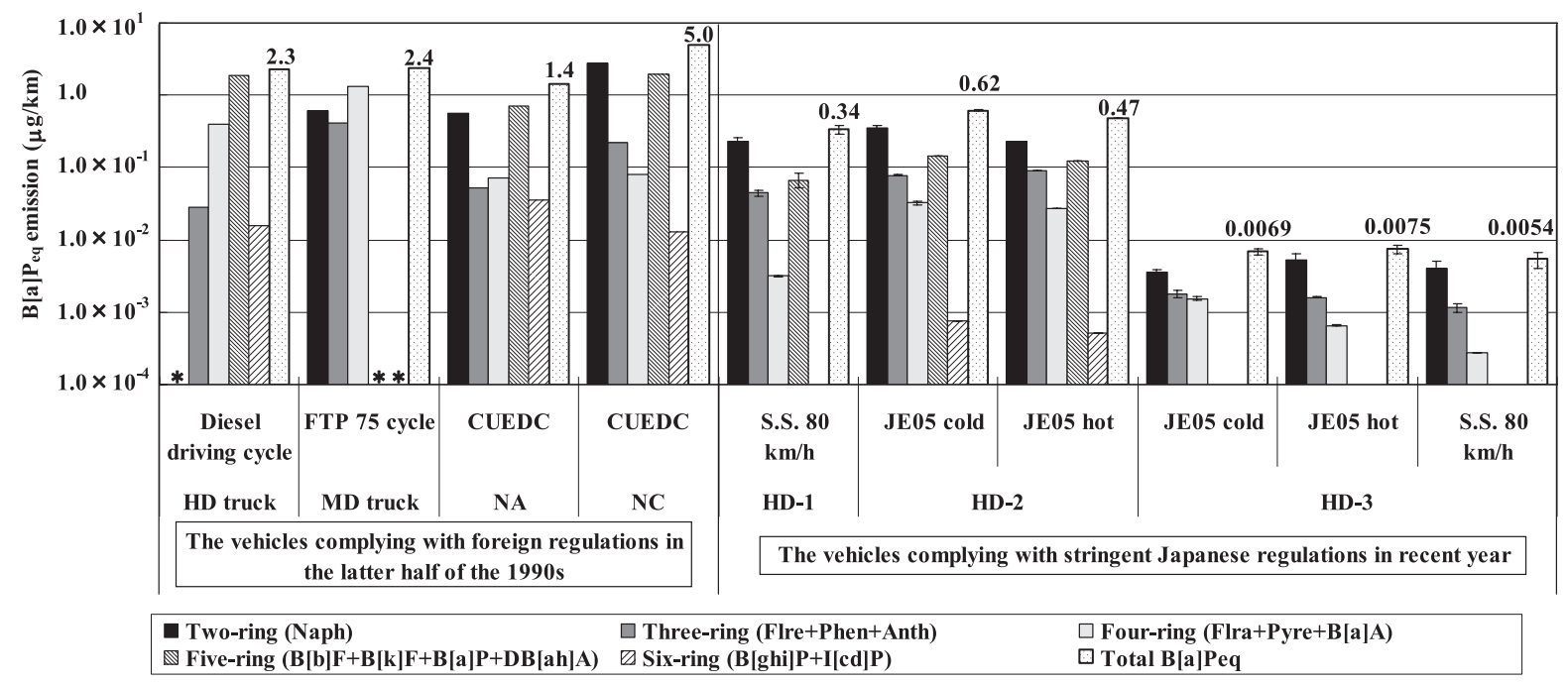

Fig. 2. Distributions of PAH Emissions in Terms of $\mathrm{B}[\mathrm{a}] \mathrm{P}_{\mathrm{eq}}$ Emissions in Our Study and Others on the Basis of the Number of Aromatic Rings

*: Two-ring (Naph), five-ring (B[b]F, B[k]F, B[a]P, DB[ah]A), six-ring (B[ghi]P, I[cd]P were not measured. The numbers on the top of the columns are total $\mathrm{B}[\mathrm{a}] \mathrm{P}_{\mathrm{eq}}$ emission. Error bar shows the range from minimum to maximum.

sured them. Our PAH emissions showed trends similar to those in the other studies in that the emissions of Naph were highest. However, most of PAH emissions from our vehicles with exhaust after-treatment devices were lower than that in the other studies. Moreover, the PAH emissions of HD-3, which had the SCR system, were vastly lower than the HD1 and HD-2 emissions. Liu et al. ${ }^{23)}$ compared 12 $\mathrm{PAH}$ emissions from diesel engine which has no aftertreatment devices with diesel particulate filter (DPF) or SCR system. For each aftertreatment devices, 10 PAHs were not detected, and 2 PAHs were reduced more than $85 \%$. The results showed these aftertreatment devices decreased PAH emissions significantly. To specify the substances having high reactivity in vehicle exhausts is need.

\section{Risk Analysis of PAH Emissions from Diesel Ve- hicles}

PAHs are carcinogenic or mutagenic and differ in their toxicity. We used TEFs ${ }^{5)}$ to estimate the cancer risks posed by PAH emissions from dieselfueled vehicles, and calculated the $\mathrm{B}[\mathrm{a}] \mathrm{P}_{\mathrm{eq}}$ from the PAH emissions which were in Tables 3 and 4 (Fig. 2).

Most the $\mathrm{B}[\mathrm{a}] \mathrm{P}_{\text {eq }}$ emissions of Naph (two-ring) and or the total of $\mathrm{B}[\mathrm{b}] \mathrm{F}, \mathrm{B}[\mathrm{k}] \mathrm{F}, \mathrm{B}[\mathrm{a}] \mathrm{P}$, and $\mathrm{DB}[\mathrm{ah}] \mathrm{A}$ (five-ring) were higher than those of other-ring PAHs. In particular, although the two-ring consisted of only Naph, with a TEF of 0.001, two-ring PAHs as a proportion of the total $\mathrm{B}[\mathrm{a}] \mathrm{P}_{\text {eq }}$ were high at $26-$
$74 \%$ (mean 54\%, S.D. $\pm 15 \%$ ).

Naph is classified in cancer risk group $2 \mathrm{~B}$ by the International Agency for Research on Cancer (IARC) ${ }^{24)}$ Because the concentrations of particulate PAHs present in vehicle exhaust that carry a high risk of cancer are decreasing owing to the use of DPFs, the relative contribution of Naph as a gaseous PAH to carcinogenesis risk is thus increasing.

Naph, which is probably emitted at the highest rates, was not measured in the study by Rogge et al. ${ }^{20)} \mathrm{B}[\mathrm{a}] \mathrm{P}$, which has a large $\mathrm{TEF}(1$; see Table 2), was not measured in the study of Schauer et al. ${ }^{21)}$ However, the $\mathrm{B}[\mathrm{a}] \mathrm{P}_{\mathrm{eq}}$ emissions in our study were substantially lower than in other studies, ${ }^{20-22)}$ and total $\mathrm{B}[\mathrm{a}] \mathrm{P}_{\mathrm{eq}}$ emissions as a cancer risk were less than approximately one tenth of their studies. Therefore, the cancer risks posed by PAHs from diesel vehicles that comply with recent regulations are generally lower than those posed by emissions from older vehicles.

Acknowledgements This work was supported in part by a grant-in-aid from the Science Research Fund of the Ministry of Education, Culture, Sports, Science and Technology (MEXT) of Japan (No. 19310045). 


\section{REFERENCES}

1) Sjogren, M., Ehrenberg, L. and Rannug, U. (1996) Relevance of different biological assays in assessing initiating and promoting properties of polycyclic aromatic hydrocarbons with respect to carcinogenic potency. Mutat. Res., 358, 97-112.

2) Shimizu, Y., Nakatsuru, Y., Ichinose, M., Takahashi, Y., Kume, H., Mimura, J., Fujii-Kuriyama, Y. and Ishikawa, T. (2000) Benzo[ $a]$ pyrene carcinogenicity is lost in mice lacking the aryl hydrocarbon receptor. Proc. Natl. Acad. Sci. U.S.A., 97, 779-782.

3) Bekki, K., Takigami, H., Suzuki, G., Tang, N. and Hayakawa, K. (2009) Evaluation of toxic activities of polycyclic aromatic hydrocarbon derivatives using in vitro bioassays. J. Health Sci., 55, 601-610.

4) U.S. Environmental Protection Agency (1984) Health effects assessment for polycyclic aromatic hydrocarbons (PAHs). EPA-540/1-86-013.

5) Nisbet, I. C. T. and LaGoy, P. K. (1992) Toxic equivalency factors (TEFs) for polycyclic aromatic hydrocarbons (PAHs). Regul. Toxicol. Pharmacol., 16, 290-300.

6) Office of Environmental Health Hazard Assessment (1994) Part B. Health assessment. In Benzo[a]pyrene as a Toxic Air Contaminant, Air Resources Board and Office of Environmental Health Hazard Assessment, California Environmental Protection Agency, Sacramento, CA.

7) Larsen, J. C. and Larsen, P. B. (1998) Chemical carcinogens. In Air Pollution and Health (Hester, R. E. and Harrison, R. M., Eds), The Royal Society of Chemistry, London, pp.33-56.

8) Boström, C., Gerde, P., Hanberg, A., Jernström, B., Johansson, C., Kyrklund, T., Rannug, A., Törnqvist, M., Victorin, K. and Westerholm, R. (2002) Cancer risk assessment, indicators, and guidelines for polycyclic aromatic hydrocarbons in the ambient air. Environ. Health Perspect., 110, 451-488.

9) Kashiwakura, K., Sasaki, S., Nakajima, T. and Sakamoto, K. (2008) Emissions of regulated and non-regulated air pollutants emitted from heavyduty diesel vehicles and their emission tendencies. J. Jpn. Soc. Atmos. Environ., 43, 67-78 (in Japanese with English abstract).

10) Hattori, H., Sogawa, Y., Yanagisawa, N., Hosoya, M., Shoji, T., Iwakiri, Y., Yamashita, T., Ikeda, T., Tanaka, S., Takahashi, K., Suzuki, T., Nakajima, T. and Tonegawa, Y. (2007) Unregulated emissions evaluation of gasoline combustion systems (lean burn/stoichiometric DISI and MPI), state of the art diesel aftertreatment technologies (DPF, urea-SCR and DOC), and fuel qualities effects (EtOH, ETBE,
Aromatics and FAME). SAE Paper, 2007-01-4082.

11) Japan Automobile Standards Internationalization Center (2008) Attachment 41 Measurement procedure for exhaust emissions from heavy-duty motor vehicles. In Automobile Type Approval Handbook for Japanese Certification Users' Guide, the Japan Automobile Standards Internationalization Center, Tokyo, pp.1-192.

12) Caplain, I., Carzier, F., Nouali, H., Mercier, A., Déchaux, J., Nollet, V., Joumard, R., André, J. and Vidon, R. (2006) Emission of unregulated pollutants from European gasoline and diesel passenger cars. Atmos. Environ., 40, 5954-5966.

13) Esteve, W., Budzinskia, H. and Villenave, E. (2006) Relative rate constants for the heterogeneous reactions of $\mathrm{NO}_{2}$ and $\mathrm{OH}$ radicals with polycyclic aromatic hydrocarbons adsorbed on carbonaceous particles. Part 2: PAHs adsorbed on diesel particulate exhaust SRM 1650a. Atmos. Environ., 40, 201-211.

14) Pipho, M. J., Kittelson, D. B. and Zarling, D. D. (1991) $\mathrm{NO}_{2}$ formation in a diesel engine. SAE Paper, 910231 .

15) Majewski, W. A., Ambs, J. L. and Bickel, K. (1995) Nitrogen oxides reactions in diesel oxidation catalyst. SAE Paper, 950374.

16) Twigg, M. V. (2006) Roles of catalytic oxidation in control of vehicle exhaust emissions. Catalysis Today, 117, 407-418.

17) Koebel, M., Elsener, M. and Madia, G. (2001) Recent advances in the development of urea-SCR for automotive applications. SAE Paper, 2001-01-3625.

18) Steinbach, S., Grünwald, J., Glückert, U. and Sattelmayer, T. (2007) Characterization of structured hydrolysis catalysts for urea-SCR. Topics in Catalysis, 42-43, 99-103.

19) Kleemann, M., Elsener, M., Koebel, M. and Wokaun, A. (2000) Hydrolysis of isocyanic acid on SCR catalysts. Ind. Eng. Chem. Res., 39, 41204126.

20) Rogge, F. W., Hildemann, L. M., Mazurek, M. A. and Cass, G. R. (1993) Sources of fine organic aerosol. 2. Noncatalyst and catalyst-equipped automobiles and heavy-duty diesel trucks. Environ. Sci. Technol., 27, 636-651.

21) Schauer, J. J., Kleeman, M. J., Cass, G. R. and Simoneit, B. R. T. (1999) Measurement of emissions from air pollution sources. 2. $\mathrm{C}_{1}$ through $\mathrm{C}_{30}$ organic compounds from medium duty diesel trucks. Environ. Sci. Technol., 33, 1578-1587.

22) Nelson, P. F., Tibbett, A. R. and Day, S. J. (2008) Effect of vehicle type and fuel quality on real world toxic emissions from diesel vehicles. Atmos. Environ., 42, 5291-5303. 
23) Liu, Z. G., Berg, D. R., Swor, T. A. and Schauer, J. J. (2008) Comparative analysis on the effects of diesel particulate filter and selective catalytic reduction systems on a wide spectrum of chemical species emissions. Environ. Sci. Technol., 42, 6080-6085.

24) International Agency for Research on Cancer (2002) IARC Monograph on the Carcinogenic Risks to $\mathrm{Hu}$ mans, 82, IARC, Lyon. 